\title{
Supporting and Inhibiting Factor of the Management of Marine Conservation Area in Sulawesi
}

\author{
Ahmad Dahlan', Jamaluddin Jompa ${ }^{2}$, Amran Saru ${ }^{3}$, A. Niartiningsih ${ }^{4}$ \\ ${ }^{1,}$ Postdoctoral Faculty of Agricultura Hasanuddin University, Makassar, Indonesia \\ ${ }^{2,3,4}$ Faculty of Fisheries and Marine Science Hasanuddin University, Makassar, Indonesia
}

\begin{abstract}
Marine Conservation Area Management is one of the tools of coastal and marine resource management that has become government policy by allocating some coastal and marine areas as a shelter for economically important fish to spawn and breed well. Analysis and study of supporting factors and obstacles to the management of marine conservation areas in Sulawesi as an effort to overcome the rate of resource degradation occurring in small islands by assessing the potential of resources owned and then analyzed so that the results can be presented in the form of program recommendations in the management and development sector Marine and fisheries in the Marine Conservation Area. This research was conducted in three locations of waters conservation area of Sulawesi island consist of Bunaken National Park of North Sulawesi Province, Kapoposang Marine Tourism Park South Sulawesi Province and Wakatobi National Park, Southeast Sulawesi Province. The study was conducted from February 2015 to January 2017. The selection of conservation areas as a research site is based on considerations, among others: 1) the location is located in different egoregion located in Sulawesi waters area, 2) different conservation area management model, and 3) The presence of different traditional societies. Methods of data collection through structured interviews, fgd, and kusioner. Respondents selected in this study were conservation area managers, communities living in conservation areas, local governments, institutions with policy-splitting authority, and institutions with interests in conservation area management. The results show that the strategy of developing marine conservation areas in the three research sites has a big challenge because it is related to the regulation or the government regulation both national and local level. The regulation makes water conservation areas have positive and negative effects on their implementation. The existence of fishermen groups should be considered to supervise and maintain the area water conservation area. This is done to reduce negative activities that damage resources. Implementation of watershed conservation management that is not only in sustainable ecological conservation but also has a goal to increase income and welfare of surrounding communities. Infrastructure development makes the achievement of sustainable use of coastal and marine resources. Infrastructure should be regarded as one of the most important parts in the context of integrated coastal zone management.
\end{abstract}

Keywords: Management, Conservation Area, Sulawesi, Bunaken, Kapoposang, Wakatobi

\section{Introduction}

Management of marine conservationArea is one of the coastal and marine resource tools management that has become government policy with allocating some coastal and marine areas as a shelter for economically important fish to spawn and breed well. Development activities of marine conservation Area are also expected to support sustainable fishing and tourism activities.James N. Sanchirico, et al (2013) explains that proactive ecosystem-based management is a turning point in marine management, formally acknowledging the need to balance marine use with potential competitiveness in it including aquaculture, energy production, conservation, fishing, and recreation.Indonesian Goverment has committed to create 20 Million $\mathrm{Ha}$ of conservation area in 2020. In the end of 2016, the Ministry of Marine Affairs and Fisheries reported the achievement rate of up to 17,3 million $\mathrm{Ha}$ (or $86,5 \%$ of the target in 2020).

Biological resources that located in the region of Sulawesi include Bunaken Park, TWP Kapoposang, and Wakatobi National Park, those are the strategic asset which can be developed as a base for economic activities for the prosperity of coastal communities and increasing local revenue. However, the intensity of exploitation activities of biodiversity resources today tend to increase and threaten its sustainability. Therefore, the effort to reorient the policy pattern of coastal and marine natural resources management is quite important and requires serious attention. Roberts, C.M. and Hawkins, J.P. (2000) explains that the Marine Protect Area Network (MPA), which is ecologically and coherently will be able to protect 30 percent of every marine habitat so we are expected to contribute significantly to the restoration of marine biodiversity and the still-productive ocean.Various forms of conservation activities have been done but the level of stakeholder participation and the expected outcomes have not been able to increase the benefits of both the ecological, economic and socio-cultural aspects, therefore it requires the effectiveness of optimal management.This is in accordance with the opinion of Ahdiat (2014) which illustrates that up to now almost in every coastal village area has a DPL, but the problem of coastal ecosystem damage is not automatically have been solved by the establishment of the DPL.

Management effectiveness is the management efforts to provide positive outcomes or impacts for both biological resources within the region and for communities associated with the area.

Based on the explanation, it is necessary to analyze and study about the supporting factors and inhibiting the management of conservation areas in Sulawesi. This 


\section{International Journal of Science and Research (IJSR) \\ ISSN (Online): 2319-7064}

Index Copernicus Value (2015): 78.96 | Impact Factor (2015): 6.391

research is conducted as an effort to overcome the rate of resource degradation occurring in the small islands of Sulawesi region by examining the potential of resources owned and then analyzed so that the results can be presented

\section{Research Method}

\section{Research Location}

This research was conducted in three locations of Sulawesi's marine conservationarea. They are Bunaken National Park North Sulawesi Province, Kapoposang Aquatic Park - South Sulawesi Province, and Wakatobi National Park - Southeast in the form of program recommendations in the management and development of marine and fisheries sector in the marine conservation Area.

Sulawesi Province. The study started from February 2015 to January 2017. The selection of conservation areas as a research site based on considerations, they are: 1) the location is in different egoregion that located in Sulawesi waters area, 2) different conservation area management model, and 3) The presence of different traditional societies. The map location of this studyis presented in Figure 1.

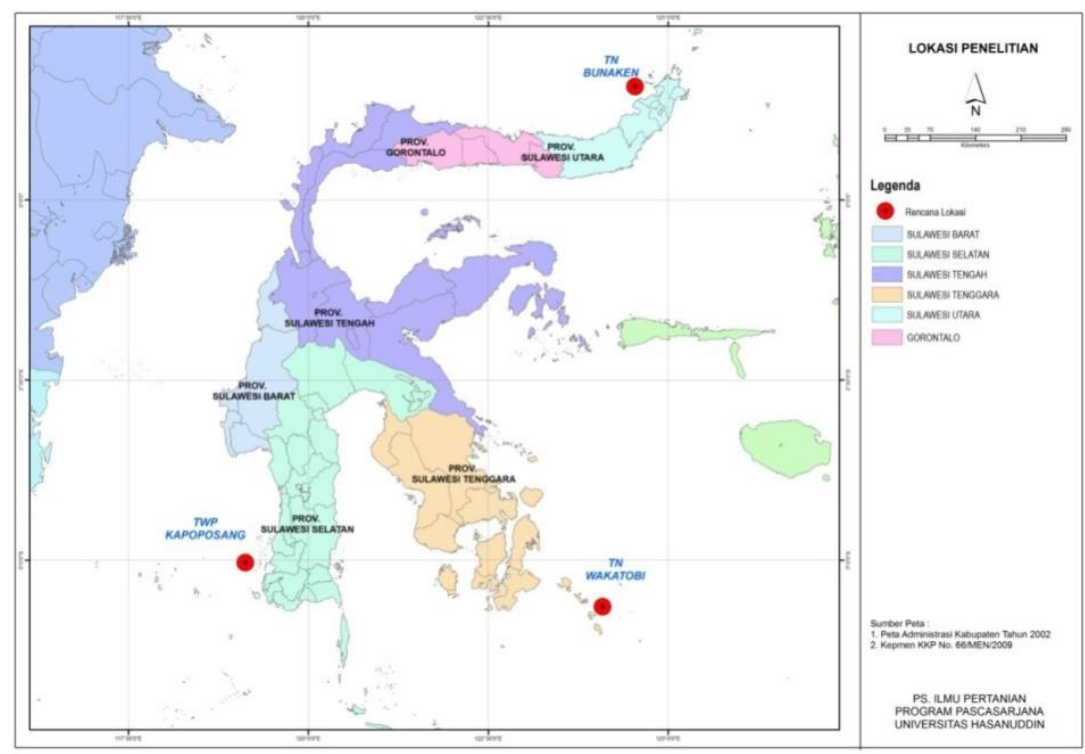

Figure 1: Resaerch Location

\section{Data Collection Method}

Primer Data is obtained by undertaking the following activities: Method of collecting data

Secondary data obtained from several sources, among others, documents from relevant agencies in the form of reports, statistical data, and other types of documents containing the management of conservation areas in each research site. The primary data obtained by doing the following activities:

1) Field Survey: To obtain the primary data conducted Interview with stakeholders (Fishermen and surrounding communities, local government officials and key informants). The key informant is intended to gain professional consideration from the respondents' expertise in determining the importance of several variables in formulating priority programs for integrated conservation area management development

2) Focus Group Discussion (FGD) with conservation area management staff, local government apparatuses and partners of Balai Taman Nasional / TWP with the aim of identifying factors that have significant strategic impact on the development of conservation area management in an integrated manner.

Selected respondents in this study were conservation area managers, communities living in conservation areas, local governments, institutions with policy-splitting authority, and institutions with interests in the management of conservation areas.Secondary data obtained from several sources including planning documents, reports, statistics, and other types of documents containing conservation area management in each research site, development of buffer zone of conservation area, and regional development

\section{Data Analysis}

Research data was analyzed using SWOT analysis. Strategic factor analysis includes analysis of internal and external factors. Internal factor analysis is done by using internal strategy factor matrix, while external factor analysis uses external factor strategy matrix. Based on the SWOT matrix, there are four alternative strategies:

1) SO strategy: use the power to take advantage of opportunities,

2) Strategy ST: use the power to deal with threats,

3) WO strategy: overcoming weaknesses to take advantage of opportunities, and

4) WT strategy: overcoming weaknesses and avoiding threats.

\section{Results and Studies}

\section{Overview of Research Location}

\section{1) BunakenNational Park (TNB)}

TNB is a national tourism area which has a total area of 89,065 ha. Covering the northern part of 75,265 ha and the southern part of 13,800 ha. Geographically, the Bunaken 


\section{International Journal of Science and Research (IJSR) \\ ISSN (Online): 2319-7064}

Index Copernicus Value (2015): 78.96 | Impact Factor (2015): 6.391

National Park is located between 10 35' 41" - 10 32' 16" LU and 1240 50' 50"- 1240 49' 22.6" East Longitude (BT), and in the southern is located between 1024 ' 0"- 10 16' 44" North Latitude (LU) and 1240 38' 3" - 1240 32' 22" East Longitude (BT). In general, the clarity in the waters of Bunaken National Park ranges from $20 \mathrm{~m}$ to 30 $\mathrm{m}$ (BTNB, 1998). Specifically in the coral reef sector, clarity is highly dependent on several environmental factors including tidal status, the presence of mangrove habitat and sea grass, and the runoff or entry of freshwater from the ground.

Bunaken National Park has a marine and coastal ecosystem consisting of several habitats, namely coral reefs, marine fish, Echinodermata, seagrass, and mangrove.Coral communities that make up the coral reefs in Bunaken National Park have a high diversity. There were 58 genera and hard coral subgenera. This ecosystem is the habitat of the most attention in Bunaken National Park so it is designated as a landscape of nature conservation and coral reefs. Hard coral cover on the edge of the reef is usually higher than the reef facing the south (up to $80 \%$ ). On the more open reefs to the waves (exposed) the maximum cover is only 50\%. The composition of hard coral communities is also diverse (Bunaken National Park, 2017).

Some fish are rare and protected like sharks(Carcharhinus melanopterus, Sphyma lewini), Dolphin fish, sea king fish(purba), Mandarin fish, and other large fish.Types of echinoderms that are commonly found in the park include sea stars including spiny sea stars(Acanthaster plancii), Snake stars, sea urchins, sea cucumbers, and sea lilies. Starfish hard coral predator (Acanthaster planci) which existed in the park within the period of 2003-2010, has been raised in large quantities $+522,871$ tails. At this time its existence is a natural threat (ibid, 2017).

The number of people living in the Bunaken landscape is almost 28,000. About 10,292 inhabitants live in the islands. Bunaken Island and Nain Island is also the highest density.

\section{2) WakatobiNational Park(TNW)}

TNWis a natural conservation area that has a variety of native ecosystems managed in a zoning system that is engaged for research, science, aquaculture, tourism and recreational tourism purposes. Wakatobi National Park has an area of 1,390,000 Ha with geographical location at $5^{\circ} 12^{\prime}-6^{\circ} 10^{\prime}$ South Latitude (LS) and $123^{\circ} 20^{\prime}-124^{\circ} 39^{\prime}$ East Longitude (BT).

The Wakatobi Islands and adjacent waters have an area of $\pm 1,390,000$ ha designated as national parks based on $S K$. Menhut No.393/Kpts-VI/1996, date 30 July 1996 and defined base on SK. Menhut No.7651/Kpts-II/2002, date 19 August 2002. TNW is managed by a zonation system established under the Decision of the Director General of Forest Protection and Nature ConservationNo.198/Kpts/DJVI/1997 date 31 December 1997, Consisting of: core zone, marine protected zone, tourism zone, local utilization zone and general utilization zone.
Wakatobi Islands are included in the area of the world's coral triangle (coral triangle center) is an area that has a diversity of coral reefs and other biodiversity. Currently, coral reef ecosystem in TNW recorded 396 hard coral species, 28 soft coral genus and 31 species of mushroom coral. The type of coral reefs that exist consists of coral reef ring(atol reef), Coral reef edge(fringing reef), Coral reefs barrier (barrier reef) and charred reefs (patch reef). Based on the results of satellite imagery, it is known that the area of coral reefs in the Wakatobi Islands is $88.161,69$ ha. Based on the coral reef fish diversity index, there are approximately 942 species of reef fish in the waters of Wakatobi (Balai TNW, 2008).

Wakatobi Islands also have non-coral ecosystems such as mangroves. There are 22 species of 13 true mangrove families, like:Rhizophora stylosa, Sonneratia alba, Osbornia octodonta, Ceriops tagal, Xylocarpus moluccensis, Scyphiphora hydrophyllacea, Bruguiera gymnorrhiza, Avicennia marina, Pemphis acidula, and Avicennia officinalis.

\section{3) Kapoposang Aquatic Park (TWP)}

The Kapoposang Islands TWP area has an area of 50,000 ha.The TWP covers 6 main islands namely Kapoposang, Papandangan, Pamangganggang, Tambakulu, Gondongbali, and Suranti, as well as a cluster of coral reefs. From the 5 islands, 3 inhabited islands are: Kapoposang Island, Papandangan, and Gondongbali.As the center of socio-economic activities, as well as the conservation of the natural resources of the Kapoposang Islands TWP, Kapoposang Island is a priority for the development of infrastructure and facilities, and the development of the area.

The geographical area of the Kapoposang Islands TWP is located at coordinates $4^{\circ} 37^{\prime}$ to $4^{\circ} 52^{\prime}$ South Latitude and $118^{\circ} 54^{\prime} 00^{\prime \prime}$ to $119^{\circ} 10^{\prime} 00^{\prime \prime}$ East Longitude.Kapoposang Island which will be the center of TWP development lies in the coordinates $04^{\circ} 41^{\prime} 00^{\prime \prime}$ South Latitude and $118^{\circ} 57^{\prime} 00^{\prime}$ "East Longitude, while Papandangan Island is the nearest neighboring island of Kapoposang Island and also the capital of the village of Mattiro Ujung where Kapoposang Island is enclosed within, located at a position around $4^{\circ} 43^{\prime} 15^{\prime \prime}$ South Latitude and $118^{\circ} 58^{\prime} 00^{\prime \prime}$ East Longitude. Distance of Kapoposang Island to Papandangan Island about 2.2 kilometers with a distance of about 10-15 minutes using a motor boat.

The livelihood of most Kapoposan Island residents is as a sub-fisherman. The most widely used fishing gear is the lanra fishing gear (monofilament gill net) and mini trawl for catching crabs and shrimp. Pukat banyara is used to search for flying fish, while fishing line (kedo-kedo) is used to catch coral fish and squid.The location of catching crabs and shrimp (with mini trawling) and flying fish (with banyara) is relatively close, which is around the island where residents live. Fish and squid fishing is done by the community when the West season arrives, where the waves are relatively large, so that fishing activities are not done in distant locations, but in reef areas around the island using traditional fishing rods. The results obtained 


\section{International Journal of Science and Research (IJSR) \\ ISSN (Online): 2319-7064 \\ Index Copernicus Value (2015): 78.96 | Impact Factor (2015): 6.391}

are only for the fulfillment of daily household consumptioni.

\section{External and Internal Factors}

The results of research on 3 marine conservation areas on Sulawesi Island have different supporting and inhibiting conditions at each location. This condition is influenced by various factors, such as policy aspects, management, natural resources, and stakeholder support to infrastructure support.Analysis of supporting and inhibiting factors of conservation area management is done by SWOT method to know the effectiveness of conservation area management in research location. The SWOT analysis describes the condition and status of management in the conservation area at the research sites are presented in Tables 1 and 2

Table 1: SWOT marine conservationArea

\begin{tabular}{|c|c|c|}
\hline \multirow{3}{*}{ Strength } & $\begin{array}{l}\text { BunakenNation } \\
\text { al Park }\end{array}$ & $\begin{array}{l}\text { 1. Support of laws and regulations related to MPA regulation and development } \\
\text { 2. The management system is governed by formal rules } \\
\text { 3. Ability to answer issues that are global } \\
\text { 4. Ability to overcome the interconnection problem } \\
\text { 5. High support of national and local NGOs in the development of marine conservation } \\
\text { 6. High government's desire for sustainable fisheries development }\end{array}$ \\
\hline & $\begin{array}{c}\text { TWP } \\
\text { Kapoposang }\end{array}$ & $\begin{array}{l}\text { 1. The beauty of nature } \\
\text { 2. Central / local government support } \\
\text { 3. Legality of area management } \\
\text { 4. Fishery Development }\end{array}$ \\
\hline & $\begin{array}{c}\text { Wakatobi } \\
\text { National Park }\end{array}$ & $\begin{array}{l}\text { 1. Strategic geographic location } \\
\text { 2. High biodiversity } \\
\text { 3. Beautiful underwater charm } \\
\text { 4. Historical and cultural diversity } \\
\text { 5. A good image as a diving destination } \\
\text { 6. Support by various government and social institutions } \\
\text { 7. Known Wakatobi as a world diving location }\end{array}$ \\
\hline \multirow[b]{3}{*}{ Weakness } & $\begin{array}{c}\text { Bunaken } \\
\text { National Park }\end{array}$ & $\begin{array}{l}\text { 1. The process of planning is from the top (top down) } \\
\text { 2. Generally less appropriate with the aspirations and culture of local communities } \\
\text { 3. Often there are overlapping policies and conflicts of interest } \\
\text { 4. Law enforcement is relatively weak and supervision is less effective }\end{array}$ \\
\hline & $\begin{array}{c}\text { TWP } \\
\text { Kapoposang }\end{array}$ & $\begin{array}{l}\text { 1. HR Managements are still low } \\
\text { 2. Supporting facilities and infrastructure are not available yet } \\
\text { 3. Community livelihood has not been developed } \\
\text { 4. Law enforcement of violations remains weak }\end{array}$ \\
\hline & $\begin{array}{c}\text { Wakatobi } \\
\text { National Park }\end{array}$ & $\begin{array}{l}\text { 1. Unclear authority of regional management between district government and TNW } \\
\text { 2. The transportation network is still minimal } \\
\text { 3. Access is difficult and expensive } \\
\text { 4. Availability of minimal infrastructure / infrastructure, and limited carrying capacity (especially } \\
\text { water and electricity) } \\
\text { 5. The quality of human resources is still weak } \\
\text { 6. Low public awareness of tourism } \\
\text { 7. Low awareness of the importance of TNN as a conservation area } \\
\text { 8. Partnership with society is still not optimal } \\
\text { 9. Weak quality of data and information about tourism wakatobiBelum tegasnya kewenangan } \\
\text { pengelolaan wilayah antara Pemda kabupaten dengan TNW }\end{array}$ \\
\hline \multirow{3}{*}{ Opportunity } & $\begin{array}{c}\text { Bunaken } \\
\text { National } \\
\text { Park }\end{array}$ & $\begin{array}{l}\text { 1. High support of local, national, international and donor NGOs on financing } \\
\text { 2. There is an international award } \\
\text { 3. High willingness / target of government to develop MPA }\end{array}$ \\
\hline & $\begin{array}{l}\text { TWP } \\
\text { Kapoposang }\end{array}$ & $\begin{array}{l}\text { 1. Rehabilitation of coastal ecosystems } \\
\text { 2. Community empowerment program of fishermen } \\
\text { 3. Increased investment in tourist areas } \\
\text { 4. Income of society is increasing }\end{array}$ \\
\hline & $\begin{array}{l}\text { Wakatobi } \\
\text { National } \\
\text { Park }\end{array}$ & $\begin{array}{l}\text { 1. There is an increasing trend of nature tourism } \\
\text { 2. The number of research programs both internationally and nationally } \\
\text { 3. Known area of Wakatobi as the center of the world's coral triangle } \\
\text { 4. Determination of Wakatobi as a world biofer by UNESCO } \\
\text { 5. The leisure time of the dive tourists } \\
\text { 6. Number of meetings from government and business from various cities } \\
\text { 7. The development of world communication technology }\end{array}$ \\
\hline \multirow[b]{2}{*}{ Threat } & $\begin{array}{l}\text { Bunaken } \\
\text { National } \\
\text { Park }\end{array}$ & $\begin{array}{l}\text { 1. The high impact of tourism } \\
\text { 2. High pollution (garbage) of household } \\
\text { 3. High habitat destruction due to unsustainable fishing } \\
\text { 4. Dependent community dependence of resources } \\
\text { 5. Natural natural degradation (natural) } \\
\text { 6. High demand for reef fish and other biota }\end{array}$ \\
\hline & $\begin{array}{c}\text { TWP } \\
\text { Kapoposang }\end{array}$ & $\begin{array}{l}\text { 1. Fishing illegally } \\
\text { 2. Effect of the extreme season }\end{array}$ \\
\hline
\end{tabular}

Volume 6 Issue 7, July 2017 www.ijsr.net 
International Journal of Science and Research (IJSR)

ISSN (Online): 2319-7064

Index Copernicus Value (2015): 78.96 | Impact Factor (2015): 6.391

\begin{tabular}{|l|l|l|}
\hline & 3. Beach Abrasion \\
\cline { 2 - 4 } & Wakatobi & \multicolumn{1}{|c|}{ Increasing number of tourists who come can impact on decreasing the carrying capacity of the } \\
National & 2. The occurrence of natural disasters \\
Park & $\begin{array}{l}\text { 3. The development of similar areas with higher advantages } \\
\text { 4. The emergence of dissatisfaction tourists }\end{array}$ \\
& $\begin{array}{l}\text { 5. The emergence of conflict between the local government and the TNW } \\
\text { 6. The emergence of conflicts between investors and communities related to land ownership } \\
\text { 7. The existence of illegal sand mining around Wakatobi beach } \\
\text { 8. There are still fishermen who use fishing methods desrtuktif in the waters of wakatobi }\end{array}$ \\
\hline
\end{tabular}

Table 1 shows each conservation area in the study location having different external factors (strengths and weaknesses) and internal (opportunities and threats) caused by various factors. Aspects of the conservation area of Bunaken National Park are in the form of legality of managers and management system that has been running effectively so that the support of various stakeholders is very high. The same thing on the Kapoposang TWP is also supported by the legality and management aspects that have been running while in Wakatobi National Park other than the legality aspect and the managers that have been running also have the potential of natural resources under the sea is good enough.

Management strategy through SWOT method in marine conservation area at research location is done by maximizing its potential can be seen in Table 2 below.

Table 2: Strategy of development of marine conservation Area

\begin{tabular}{|c|c|c|}
\hline \multirow{4}{*}{$\begin{array}{l}\text { Taman } \\
\text { Nasional } \\
\text { Bunaken }\end{array}$} & SO Strategy & $\begin{array}{l}\text { 1. Improving strong oversight from both local government and NGOs due to the MPA development } \\
\text { regulation (S-1,2,5,6 \& O- } 1) \\
\text { 2. Improve cooperation between institutions both national and international institutions (S-3,4,5 \& O- } \\
2,3)\end{array}$ \\
\hline & WOStrategy & $\begin{array}{l}\text { 1. Optimization of cooperation with NGOs in the preparation of planning (W-1,2,3,4 \& O-1,2,3) } \\
\text { 2. Optimizing the implementation of activities of the local community based on the prevailing culture } \\
\text { and rules (W-3.4 \& O-3) }\end{array}$ \\
\hline & STStrategy & $\begin{array}{l}\text { 1. Improve the performance of state apparatus and infrastructure in supervising the implementation of } \\
\text { tourism activities ( } \mathrm{S}-1,2,3,4 \text { \& } \mathrm{T}-1,2,3) \\
\text { 2. Creating alternative livelihood opportunities for people with high levels of tourism }(\mathrm{S}-1,2 \& \mathrm{~T}-3,4,5) \\
\text { 3. Establishment of zoning rules for fishing locations at tourism sites (S-3,4 \& T-5,6) }\end{array}$ \\
\hline & WTStrategy & 1. Establishment of appropriate legislation on tourism policy (W-1,2 \& T-1,2,3,4,5,6) \\
\hline \multirow{4}{*}{$\begin{array}{c}\text { TWP } \\
\text { Kapoposang }\end{array}$} & SOStrategy & $\begin{array}{l}\text { 1. Increase the territory of arrest and tourism based on zoning }(\mathrm{S}-1,2,3,4 \& \mathrm{O}-1,2,3) \\
\text { 2. Creation of alternative daily eye-catchers by utilizing tourism locations }(\mathrm{S}-3,4 \text { \& } \mathrm{O}-3,4)\end{array}$ \\
\hline & WOStrategy & $\begin{array}{l}\text { 1. Optimization of cooperation with NGOs in the preparation of planning (W-1,2,3,4 \& O-1,2,3) } \\
\text { 2. Optimizing the implementation of activities of the local community based on the prevailing culture } \\
\text { and rules (W-3.4 \& O-3) }\end{array}$ \\
\hline & STStrategy & $\begin{array}{l}\text { 1. Improve the performance of state apparatus and infrastructure in supervising the implementation of } \\
\text { tourism activities }(\mathrm{S}-1,2,3,4 \& \mathrm{~T}-1,2,3) \\
\text { 2. Creating alternative livelihood opportunities for people with high levels of tourism ( } \mathrm{S}-1,2 \& \mathrm{~T}-1,2,3)\end{array}$ \\
\hline & WTStrategy & 1. Establishment of appropriate legislation on tourism policy (W-1,2 \& T-1,2,3) \\
\hline \multirow[t]{4}{*}{$\begin{array}{l}\text { Taman } \\
\text { Nasional } \\
\text { Wakatobi }\end{array}$} & SOStrategy & $\begin{array}{l}\text { 1. Increasing tourism promotion not only of national scale but also to international scale (S-1,2,3,4 \& O- } \\
1,2,3,4) \\
\text { 2. Increased access and infra-structure of both marine tourism and historical tourism on Wakatobi Island } \\
\text { (S-5,7 \& O-5,6,7) } \\
\text { 3. Improvement of international scale services both in tourist sites and outside tourist sites (S-6 \& O-6.7) }\end{array}$ \\
\hline & WOStrategy & $\begin{array}{l}\text { 1. Optimization of cooperation with NGOs in the preparation of planning (W-1,2,3,4 \& O-1,2,3,4) } \\
\text { 2. Optimizing the implementation of activities of the local community based on the prevailing culture } \\
\text { and rules (W-3,4 \& O-5,6,7) }\end{array}$ \\
\hline & STStrategy & $\begin{array}{l}\text { 1. Improve the performance of state apparatus and infrastructure in supervising the implementation of } \\
\text { tourism activities (S-1,2,3,4 \& T-1,2,3) } \\
\text { 2. Creating alternative livelihood opportunities for people with high levels of tourism }(\mathrm{S}-1,2 \& \mathrm{~T}-3,4,5) \\
\text { 3. Establishment of zoning rules for fishing locations at tourism sites (S-3,4 \& T-5,6,7,8) }\end{array}$ \\
\hline & WTStrategy & 1. Establishment of appropriate legislation on tourism policy (W-1,2 \& T-1,2,3,4,5,6,7,8) \\
\hline
\end{tabular}

Based on the three matrices in each of the marine conservation areas above Itshows that there are similarities in internal and external factors in each conservation area. The main strength or driving factor in these three waters areas is the high demand of the government in the development of conservation areas. This is indicated by the legislation that is used as a legal umbrella in the management of the three areas. The biggest obstacle in the management of conservation areas in these three waters areas is the non-optimal supervisory factor from both the government apparatus and the local communities themselves in creating an optimal and sustainable conservation area.

Conservation area management activities must be sustainable both in terms of management systems, ecology, and improving the level of community welfare. The threat issues in the management of marine protectedareas within the three research sites will have a significant impact on ecological sustainability and community welfare and lead to

Volume 6 Issue 7, July 2017 www.ijsr.net 


\section{International Journal of Science and Research (IJSR) \\ ISSN (Online): 2319-7064}

Index Copernicus Value (2015): 78.96 | Impact Factor (2015): 6.391

degradation of natural resources, which must be handled cross-sectorally through management policies capable of impacting the sustainability of marine and fisheries development. The implementation of the regional autonomy system provides a very strategic capability in the management of watershed areas as a source of livelihood for sustainable communities.

Agardi Tundi (2002)reports that an implementer of conservation activities shall determine the level of sustainability, see the exploitation activities of the species and be able to account for changes in environmental conditions that may impact on the sustainability of biodiversity as a whole. Yasa (2010) explains that sustainable development demands the management of natural resources in such a way as to ensure long-term availability and quality. Achieving the right balance between economic growth and conservation of natural resources is a key objective in sustainable development in watershed areas.

\section{Management of Conservation Areas}

Based on the internal and external matrix of SWOT analysis (Table 2) illustrates that the dominance of the development of marine conservation area development strategies in the three research sites has great challenges to be able to solve management problems related to both national and local government regulations. Implementation of regulations relating to the management of marine conservation areas can provide positive and negative effects. Each location of the conservation area is experiencing a weakness in the overlap of policy between the central government and local government in managing the aquatic conservation area. Nessa et al. (2015) explains the weak role of the government to push the policy of utilization of natural resources into the gap of increasing the level of damage, let alone the more terpimpit the economy.

Inhibiting factors of conservation area management should be a stimulus for both central and local governments to be able to develop synergistic regulations so as to raise awareness of all parties engaged in conservation area areas to be able to create marine resource governance in conservation areas to be more prudent and sustainable. Christopher M. Weible and Paul A. Sabatier (2005) explain that core policy is a faith that serves as a key perceptual filter for actors within the policy subsystem to determine supporters and inhibitors in determining potential coastal management information.

Conservation of marine biological resources is one form of management of marine resources ecosystem from damage caused by human activities. Uncontrolled use of natural resources in coastal areas can cause damage to natural resources. The existence of fishermen groups should be considered to supervise and maintain aquatic conservation area. This is done to reduce negative activities that impact on resource damage.

In addition, with the allocation of funds from the government to help communities around the watershed conservation area aims to supervise its own conservation activities or supervision patrol by community groups running well.Pomeroy et al. (2004) Explaining the cultural practices of the group or ethnicity, attitudes and beliefs that certain coastal communities can directly influence the biophysical conditions so as to enhance the control of the desired ecological area.

Implementation of watershed conservation management is an effort not only in sustainable ecological conservation but also has a goal to increase the income and welfare of surrounding communities. Management of marine conservation areas will be able to increase the income of the community directly both in terms of utilization of fishery resources that exist around or outside the fishery resources caused by the location of conservation areas are able to create business opportunities in the tourism sector. In supporting the effectiveness of the management of conservation areas, economic expectations do not only develop in waters and around conservation areas.Community efforts in trade should also be able to develop in the tourism sector. High levels of community participation in the management of aquatic conservation should be able to be stimulated by a balanced economic improvement in accordance with the role in the participation of conservation area management. Creation of alternative livelihoods in conservation areas in all three-research sites should be able to be supported with adequate facilities and infrastructure(Pomeroy et al. 2004).

Effective management of watersheds, coastal areas and small islands can be achieved through good zoning management and management planning, the availability of competent human and management resources, the availability of good infrastructure and support facilities, as well as regional management efforts undertaken Synergistically and unified. Management of marine conservation areas and infrastructure development have a very dominant linkage in the form of a common goal between the management of coastal areas and infrastructure development is to achieve the sustainable use of coastal and marine resources. In this context, infrastructure development should be regarded as one of the most important areas in the management of integrated coastal areas (Abecasis et al 2015).

In the management of water conservation areas to achieve sustainable development of coastal and marine areas, reduce the risk or vulnerability of coastal areas as well as communities and infrastructure and social-economic activities both against various natural disaster threats, as well as negative impacts of socio-economic activities of the community, and to maintain Basic ecological processes, life support systems and marine biodiversity in coastal areas.

\section{Conclusion}

1) The strategy of developing marine conservation areas in the three research sites poses great challenges as they relate to both national and local regulations or regulations. The regulation makes water conservation areas have positive and negative effects on their implementation.

2) The existence of fishermen groups should be considered to supervise and maintain regional waters conservation

\section{Volume 6 Issue 7, July 2017 www.ijsr.net}




\section{International Journal of Science and Research (IJSR) \\ ISSN (Online): 2319-7064 \\ Index Copernicus Value (2015): 78.96 | Impact Factor (2015): 6.391}

area. This is done to reduce negative activities that damage resources.

3) Implementation of watershed conservation management that is not only in sustainable ecological conservation but also has a purpose to increase income and prosperity of the surrounding community.

4) The development of infrastructure makes the achievement of sustainable use of coastal and marine resources. Infrastructure should be regarded as one of the most important parts in the context of integrated coastal zone management.

\section{References}

[1] Ahdiat. 2014. Evaluation The Effectiveness of Area Marine Management Park Kapoposang and Conservation Area The Sea Pangkep regency. Universitas Hasanuddin. Tesis.

[2] BPS Wakatobi. 2017. Wakatobi Regency in Figures. Book. Wakatobi.

[3] BPS Pangkep. 2017. Pangkep Regency in Figures,. Book. Pangkep.

[4] Clifton, J. (2003). Prospects for co-management in Indonesia's marine protected areas. MarinePolicy 27, 389-395.

[5] COREMAP, 2006. Guidebook Regional Management Protection The Sea Community-Based. Book. COREMAP. Jakarta.

[6] Day, J. 2002. Zoning lessons from the Great Barrier Reef Marine Park. Ocean and Coastal Management, 45: 139-156

[7] Directorat Geneal of Maritime Decision Coastal and Small Islands. 2012. Guidelines Technical Evaluation The Effectiveness of Marine Conservation Area Management, Coastal and Small Islands (E-KKP3K). The Director Geneal of Maritime Decision Coastal and Small Islands nomor KEP.44/KP3K/12. Jakarta.

[8] Rita C. Abecasis, Pedro Afonso, Ana Colaço, Nancy Longnecker, Julian Clifton, Luisa Schmidt, and Ricardo S. Santos. 2015. Marine Conservation in the Azores: Evaluating Marine Protected Area Development in a Remote Island Context. Frontiers In Marine Science. Vol. 2. Article 104.www.frontiersin.org. diakses pada tanggal 18 Juli 2017 Pukul 22.30.

[9] Taman Nasional Bunaken. INFORMASI/INDO ENGLISH/ tn_bunaken.htm.www.dpehut.go.id (16 Juli 2017)

[10] Pomeroy R.S, John E.Parks, Lani M.W. 2004. How is Your MPA Doing? A Guidebook of Natural and Social Indicators for Evaluating Marine Protected Area Management Effectiveness. IUCN. UK.

[11] Yasa I.G.W. and Murjana. 2010. Economic Gree, Production Clean and Creative Economy: Approach Risk Enviroment Prevent to Economic Growth Quality in Bali Province. Journal of Bumi Lestari. pp 285-294.

Volume 6 Issue 7, July 2017 www.ijsr.net 